\title{
Yhteishankintakoulutuksen idea ja todellisuus
}

\author{
Kommentti Heikki Silvennoisen ja Kirsi Kuitusen artikkelin johdosta
}

On erinomaista, että työvoimapoliittinen koulutus kiinnostaa tutkijoita. Heikki Silvennoisen ja Kirsi Kuitusen artikkeli vaatii kuitenkin täydennykseksi eräitä koulutuksen hankkijan kommentteja.

Koulutustutkijoiden olettaisi tuntevan ammatillisen aikuiskoulutuksen kolmijaon: omaehtoinen, työvoimapoliittinen ja henkilöstökoulutus. Otsikossa mainittua "työvoimapoliittista henkilöstökoulutusta" ei siis ole olemassa. Henkilöstökoulutuksesta työvoimapoliittinen yhteishankintakoulutus eroaa siinä, että yritys ei päätä siitä yksin eikä rahoita sitä yksin, vaan yhteistyössä työvoimaviranomaisen kanssa. Henkilöstökoulutus on vain yrityksen vastuulla ja se kohdentuu olemassa olevaan henkilöstöön.

Vuoden 1991 alusta voimaan tullut laki työvoimapoliittisesta aikuiskoulutuksesta mahdollisti koulutuksen yhteishankinnat yritysten kanssa. Yhteishankintakoulutuksen ideana on mahdollistaa panoksia yhdistämällä sellaisten yrityskohtaisten koulutushankkeiden toteuttaminen, joihin sisältyy suuri työvoimapoliittinen intressi. Tämä intressi voi olla työttömien rekrytointi yrityksen palvelukseen, tuottavuuden, organisaation toimivuuden ja laadun parantaminen tai tilapäisestä tuotteiden kysynnän vähäisyydestä johtuvan lomautusajan järkevä käyttö yrityksen ja sen henkilöstön ammattitaidon kehittämiseen.

Yhteishankintojen volyymi on ollut vuosina 1991-94 6-7 prosenttia koko työvoimakoulutuksesta. Esimerkiksi vuonna 1994 yhteishankintoja toteutettiin 387000 opiskelijatyöpäivää. Työhön sijoittuminen on yleensä erinomaisella tasolla: esimerkiksi rekrytointikurssin hyväksyttävästi suorittaneet otetaan yleensä kaikki yrityksen palvelukseen. Yhteishankinta on siis keino kehittää nopeasti työttömien ammattitaitoja yritysten kysyntää vastaaviksi. Työvoimatoimisto voi etsiä yritykselle sopivat rekrytointikoulutukseen hakijat, jotka voidaan testata ja haastatella ennen hyväksymistä. Esimerkiksi elektroniikkateollisuudessa on toteutettu merkittäviä ja menestyksekkäistä yhteishankintoja, jotka ovat avanneet uusia työpaikkoja työttömille.

Artikkelissa esitetty kyselytutkimus on tehty vain yhtä työvoimapiiriä koskien juuri uuden ostojärjestelmän käyttöön ottamisen jälkeen. Kirjoittajat toteavat, ettei työnantajan maksuosuutta ole laissa tarkemmin määritelty. Ei olekaan. Kuinka lailla voitaisiin markkinataloudessa määrätä koulutuspalvelujen tuottaja myymään koulutus tiettyyn hintaan ja työnantaja maksamaan tästä tietty osuus? Koulutushankintojen hinnanmuodostus tapahtuu siis markkinoilla. Yhteishankinnoissa myös yrityksen edustajat voivat toimia kouluttajina, mutta koulutusta hankitaan yleensä oppilaitoksilta. Tyypillistä on esimerkiksi teoriajakson hankkiminen ammatilliselta oppilaitokselta ja työtaitojen kouluttaminen yrityksessä.

Yhteishankintojen kuva on muuttunut siten Silvennoisen ja Kuitusen kyselytutkimuksen. Vuosina 1991 ja 1992 lomautusten vaihtoehtona järjestettävä koulutus oli vallitsevaa, mutta työvoiman kysynnän elvyttyä vuodesta 1994 lähtien ovat rekrytointikoulutukset kasvaneet ja lomautukset väistyneet. Vuotta 1995 koskevien ennakkotietojen perusteella yrityskohtaisesta koulutuksesta (josta kaikki ei ole välttämättä yhteishankintaa) 46 prosenttia oli rekrytointikoulutusta, vain 23 prosenttia lomautuskoulutusta ja 31 prosenttia muuta yrityskoulutusta. Yrityskoulutuksen suorittaneista 93 prosenttia sijoittui työhön kahdessa kuukaudessa suorittamisesta, kun koko ammatillisen työvoimakoulutuksen suorittaneista 40 prosenttia sijoittui välittömästi työhön vuonna 1995.

Rekrytointikoulutuksessa työvoimapoliittinen intressi veronmaksajien varojen käyttöön yrityskohtaiseen koulutukseen on se, että näin saadaan työttömistä koulutuksen avulla mahdollisimman nopeasti ja joustavasti yrityksen kysymiä ammattityöntekijöitä ja heidät työhön. Rekrytointi toki tapahtuisi yleensä muutoinkin, mutta veronmaksajien panostuksella ja työviranomaisen mukanaololla varmistetaan se, että rekrytoidaan työttömiä eikä esimerkiksi kilpailevan yrityksen työntekijöitä, mikä aiheuttaisi palkkainflaatiota.

Kyselytutkimuksen perusteella osallistujat näyttävät varsin tyytyväisiltä saamaansa koulutukseen. Tuloksia on pidettävä yleensä osoituksena koulutuksen onnistumisesta. Kun tekijät siteeraavat dosentti Pauli Juutin työvoimakoulutuksen yritystasoisen vaikuttavuuden tutkimuksesta työvoimakoulutuksen käyttöä estäviä tekijöitä, todettakoon vastaavasti, että Juutin tulosten mukaan käyttöä edistäviä tekijöitä on rahallinen tuki yrityksille, työvoimaviranomaisten ammattitaito koulutuksen järjestämisessä ja opettajien hyvä taso. Juuti muuten suosittelee johtopäätöksissään sitä, että suurempi osa työvoimakoulutuksesta annettaisiin yritysten toteutettavaksi. Olen samaa mieltä. 
Työvoimakoulutuksessa yleensä onkin otettu käyttöön uusia koulutusmalleja, jossa tietyn alan yritysverkosto ja oppilaitokset toimivat yhdessä kouluttajina. Ensi kokemukset esimerkiksi Vaasan työvoimapiiristä ovat lupaavia.

Silvennoisen ja Kuitusen mukaan jotkut työnantajat ovat käyttäneet saamansa tuen muuhun kuin koulutukseen ja myös jotkut osallistujat ovat raportoineet tehneensä normaalia työtään. Tämä ei ole yhteishankintakoulutuksen tarkoitus. Mikäli tällaista esiintyy, tulee opiskelijoiden ottaa heti yhteys paikalliseen työvoimaviranomaiseen, jonka tulee puuttua tilanteeseen.

Kun tutkimuksessa esitettyyn väittämään "suurin osa koulutuksesta ei juurikaan eronnut tavallisesta työpäivästä" 24 prosenttia vastaa myönteisesti, ei tämä osoita sitä, mikä osuus yhteishankinnoista on mahdollisesti käytetty väärin ja koulutusta koskevan sopimuksen vastaisesti. Olisi täsmennettävä, missä suhteessa se ei eroa tavallisesta työpäivästä. Onko tutkijoiden käsitys koulutuksesta ja oppimisesta tässä varsin perinteinen "luokkahuoneopetus", mikä ei yleensä työelämälähtöisessä koulutuksessa ole vallitseva malli? Niinpä ammatilliseen työvoimakoulutukseen kuuluu olennaisena osana työharjoittelu yrityksissä, minkä laatua seurataan. Parasta koulutusta ja oppimista voikin olla se, jos pääsee opiskelemaan omassa tai tulevassa työympäristössään, todellisessa sosiaalisessa kontekstissa. Koulutuksen ei tarvitse mielestäni välttämättä erotakaan työnteosta muutoin kuin sikäli, että siinä on systemaattinen kvalifikaatioita kehittävä ote. Ammatillisen koulujärjestelmäkoulutuksemme ongelma onkin se, että se on edelleen liian paljon perinteisen koulutuskäsityksen vanki.

Yhteishankinnassa on kyse sopimuksesta tietyn koulutuksen järjestämisessä. Tuki yritykselle on siis luonteeltaan koulutuksellista. Koulutus suunnitellaan yrityksen ja työvoimaviranomaisen yhteistyönä ja siitä laaditaan sopimus. Työvoimaviranomaisilla ei ole mahdollisuuksia käydä valvomassa jokaista koulutustilaisuutta erikseen, vaan koulutushankkeen lähtökohdan on oltava niin varmalla pohjalla, ettei väärinkäytöksiä tapahdu. Kouluttavan oppilaitoksen kuuluu myös valvoa yrityksissä toteutettavaa osuutta, kuten työvoimakoulutuksessa normaalisti työharjoitteluakin. Lisäksi luotamme opiskelijapalautteeseen, joka paljastaa koulutuksen mahdolliset epäkohdat.

Yleensä sekä opiskelijat että työnantajat ovat olleet yhteishankintoihin tyytyväisiä. Koska yhteishankintakoulutuksessa opittuja taitoja päästään heti soveltamaan työssä, koulutustakin arvioidaan työn ja yrityksen kehittymisen kautta.

Työministeriö on tyytyväinen työvoimakoulutuksen yhteishankinnoilla aikaansaatuihin tuloksiin. Opiskelijoiden ja työnantajien palaute on ollut valtaosin hyvin myönteistä - kuten Heikki Silvennoisen ja Kirsi Kuitusen tuloksetkin. Tulkinnoista voidaan tietysti keskustella.

Heikki Räisänen

valtiot.tri., erikoistutkija

Työministeriö

Työvoiman koulutus- ja kuntoutusyksikkö 